Adriana Biedroń

Akademia Pomorska w Słupsku

adriana.biedron@apsl.edu.pl

\title{
ROLA PAMIĘCI ROBOCZEJ W NAUCE JĘZYKA OBCEGO I WIELOJĘZYCZNOŚCI
}

\section{The role of working memory in foreign language learning and multilingualism}

Working memory is now one of the most frequently studied individual differences in various fields of science, including cognitive and developmental psychology, neuroscience, and second language acquisition. It affects cognitive functioning, including all aspects of learning a foreign language, and its deficits severely impair learning outcomes. This article focuses on practical application of this knowledge (see Gregersen \& Maclntyre, 2014) in a language classroom. To this end, we first present a definition of a working memory and its components altogether with their relevance for various areas of foreign language learning. This is followed by a review of research on linguistically gifted individuals, polyglots, and savants as well as bilinguals from the perspective of memory aptitude. The last section offers some pedagogical implications, such as aptitude-treatment interaction and working memory training. The article ends with suggestions for further research in this area.

Keywords: working memory, phonological loop, central executive, foreign language learning, working memory training

Słowa kluczowe: pamięć robocza, pętla fonologiczna, centralny system wykonawczy, nauka języka obcego, trening pamięci roboczej 


\section{Wstęp}

Pamięć robocza (PR) jest jedną z różnic indywidualnych cieszących się obecnie największym zainteresowaniem w psychologii poznawczej i rozwojowej, neuronaukach, kognitywistyce, neurogenetyce i językoznawstwie (Wen, Mota i McNeill, 2015). Uczeni zajmujący się dziedziną akwizycji języka pierwszego i drugiego oraz dydaktyką nauczania języka obcego analizują wpływ PR na różne aspekty przyswajania, przetwarzania i produkcji językowej z kilku powodów. Po pierwsze jest to zmienna mająca statystycznie istotny wpływ na funkcjonowanie poznawcze, w tym m.in. czytanie, pisanie, rozumienie dyskursu, naukę gramatyki, fonetyki, słownictwa oraz inne procesy związane z nauką języka (Juffs i Harrington, 2011; Linck i in., 2013; Linck i in., 2014; Skehan, 2015; Wen, 2015). Po drugie PR stanowi komponent współczesnych modeli zdolności językowych (Robinson, 2002; Skehan, 2002) i podstawę testów zdolności językowych (Doughty i in., 2010), a jej deficyt znacznie upośledza możliwości nauki języka obcego (Gathercole, Lamont i Alloway, 2006). Co istotne, osoby dwujęzyczne mają efektywniej działającą PR, zarówno w zakresie przechowania informacji, jak i zarządzania zasobami uwagi. Badania Bialystok i jej zespołu (Morales, Calvo i Bialystok, 2013), stanowią dowód na pojemniejszą PR u dzieci dwujęzycznych w porównaniu z jednojęzycznymi, zwłaszcza w zakresie zasobów uwagi. Ponadto PR jest zmienną modyfikującą skuteczność instrukcji językowej, ponieważ jej nadmierne obciążenie ogranicza zdolność do świadomego zwrócenia uwagi na formę (ang. noticing). Zbytnie obciążenie PR może spowodować, że korekta nie będzie dostrzeżona albo odpowiednio zinterpretowana, a niewystarczające zasoby uwagi mogą uniemożliwić próbę autokorekty (Gregersen i MacIntyre, 2014; Li, 2015). Kolejnym powodem rosnącego zainteresowania tą różnicą indywidualną jest możliwość jej rozwoju wskutek treningu, którego skutki są statystycznie istotne i trwałe (Söderqvist i Nutley, 2015), co stanowi wyjątek wśród innych, zasadniczo niemodyfikowalnych czynników poznawczych, jak np. pozostałe zdolności językowe czy inteligencja (Plomin i Deary, 2015).

Niniejszy artykuł stanowi podsumowanie wybranych badań nad PR związanych z nauką języka drugiego oraz prezentuje kilka praktycznych porad dla nauczycieli języków obcych w zakresie pracy z uczniami o różnej pojemności PR i różnych zasobach uwagi. Na początku zostanie krótko wyjaśnione pojęcie PR i jej miejsce $w$ badaniach nad przyswajaniem języka, następnie zostaną omówione symptomy deficytu tej zmiennej i możliwe sposoby interwencji pedagogicznej mające na celu kompensację niskich zdolności pamięciowych bądź treningu ukierunkowanego na ich rozwój. Na końcu zostanie umieszczone podsumowanie oraz sugestie dotyczące dalszych kierunków badań. 


\section{Pojęcie pamięci roboczej i jej miejsce $w$ badaniach nad przyswajaniem języka drugiego}

PR definiujemy jako rodzaj pamięci, który z jednej strony stanowi tymczasowy magazyn informacji, z drugiej zaś wpływa na zdolność do kontroli uwagi w celu bieżącego manipulowania informacją (Bunting i Engle, 2015: XVII). Jest to zatem rodzaj aktywnej, „pracującej” pamięci, która wymaga zaangażowania dużych zasobów uwagi, co odróżnia ją od pamięci krótkotrwałej, angażującej uwagę w małym stopniu. Przykładem działania PR może być konwersacja w języku obcym pomiędzy średniozaawansowanym uczniem a obcokrajowcem. Jest to sytuacja wymagająca kontroli nad doborem słownictwa, struktur i właściwą wymową oraz koordynacji zrozumienia interlokutora i skutecznego przekazania informacji pomimo deficytów językowych. Zadanie takie angażuje tak olbrzymie zasoby PR, że często uczeń nie jest w stanie w ogóle skupić się na poprawności, gdyż cała energia zostaje wydatkowana na treść przekazu. Z tego samego powodu uczniowie na niższych poziomach zaawansowania nie reagują na implicytną poprawę formy przez nauczyciela, polegającą na przeformułowaniu niepoprawnej wypowiedzi przy zachowaniu treści (ang. recast), traktując ją jako „powtórzenie tego samego w inny sposób” (Mackey i in., 2002). Przyczyną takiego stanu rzeczy jest słaba kontrola nad językiem wynikająca z niskiego stopnia kompetencji lub niska pojemność PR i słabe zasoby uwagi. Zrozumiała jest zatem potrzeba zminimalizowania bądź zrekompensowania tych deficytów w celu podniesienia skuteczności nauki języka drugiego (Skehan, 2015).

W teorii przyswajania języka drugiego najpopularniejszy jest klasyczny model skonstruowany przez Baddeleya i Hitcha (1974; zob. też Baddeley, 2000, 2015). Zawiera on trzy magazyny pamięciowe: 1) pętlę fonologiczną związaną z przechowaniem informacji werbalnej, 2) szkicownik wzrokowo-przestrzenny, który, jak sama nazwa wskazuje, przechowuje informacje wizualno-przestrzenne oraz 3) bufor epizodyczny, w którym odbywa się integracja i przechowywanie informacji. Elementem czwartym jest centralny system wykonawczy, pełniący nadrzędną funkcję nad magazynami pamięci i odpowiadający za kontrolę zasobów uwagi sterujących procesami poznawczymi. PR, niezbędna zarówno w życiu codziennym, jak i w złożonych operacjach mentalnych, jest wysoko skorelowana z inteligencją (Engle i in., 1999), lecz nie jest z nią tożsama.

Rola PR w przyswajaniu języka drugiego jest systematycznie badana i dotyczy praktycznie wszystkich jego aspektów: podsystemów języka, umiejętności językowych, dwujęzyczności, sukcesu w nauce, osiągania bardzo wysokiej kompetencji, skuteczności instrukcji językowej, ADHD oraz dysleksji. Pomimo wielu nierozwiązanych problemów badawczych i wątpliwości PR jest uważana za bardzo istotną zmienną we wszystkich tych obszarach (Miyake i 
Friedman, 1998; Sawyer i Ranta, 2001; Robinson, 2003; Kormos i Sáfár, 2008; Doughty i in., 2010; DeKeyser i Koeth, 2011; Juffs i Harrington, 2011; Wen i Skehan, 2011; Biedroń i Szczepaniak, 2012; Doughty i in., 2013; Linck i in., 2013; Linck i in., 2014; Skehan, 2015; Wen, 2015). Spośród czterech elementów modelu Baddeleya dwa odgrywają istotną rolę w procesie przyswajania języka: pętla fonologiczna i centralny system wykonawczy. Pierwotnie uwagę skierowano na pętlę fonologiczną ze względu na jej rolę w uczeniu się nowego słownictwa. Jak przypuszczano, ewoluowała ona w celu uczenia się nowych słów i dźwięków w języku pierwszym, dzięki czemu została uznana za ekwiwalent mechanizmu akwizycji języka (ang. language acquisition device) (Baddeley, Gathercole i Papagno, 1998). Kolejne badania wskazały na rolę centralnego systemu wykonawczego związanego z zasobami uwagi, którego zadaniem jest utrzymanie istotnej informacji w stanie aktywnym lub zapewnienie dostępu do tej informacji w sytuacji interferencji, konfliktu lub dystrakcji. Sytuacja taka wymaga alokacji zasobów uwagi i selekcji informacji w celu zablokowania dostępu do bodźców nieistotnych przy jednoczesnym skupieniu się na istotnych (Conway i in., 2008).

W badaniach językoznawczych wykazano, że dwa wyżej opisane komponenty PR odgrywają odmienną rolę $\mathrm{w}$ różnych aspektach przyswajania i przetwarzania języka obcego (Juffs i Harrington, 2011; Williams, 2012; Wen, 2015). Pętla fonologiczna, będąca znacznie lepiej zbadanym elementem, jest związana z nauką słownictwa, zwrotów, kolokacji, konstrukcji morfo-syntaktycznych oraz nauką gramatyki (Williams i Lovatt, 2003; Ellis, 2012; Martin i Ellis, 2012). Centralny system wykonawczy zaangażowany jest w procesy złożone, jak produkcja i rozumienie mowy, monitorowanie mówienia, autokorekta oraz interakcja, a także nauka gramatyki, aczkolwiek ten ostatni problem wymaga dalszych badań (Linck i in., 2014). Wspominamy tylko o tych aspektach, które zweryfikowano empirycznie, tak więc rola systemu centralnego oraz pozostałych elementów PR nie jest do końca poznana. Z punktu widzenia dydaktyki języka obcego za najbardziej interesujące można uznać trzy nurty badań:

1. PR w kontekście zdolności językowych;

2. PR w kontekście wielojęzyczności;

3. PR jako zmienna poddająca się treningowi.

Dwa pierwsze nurty zostaną omówione w kolejnej sekcji ze względu na wspólne cechy osób należących do tych grup.

\section{Pamięć robocza jako zdolność językowa i cecha osób wielojęzycznych}

W 1998 roku Baddeley, psycholog i twórca pojęcia PR, postawił hipotezę, że poligloci mają przewagę nad uczniami posługującymi się wyłącznie językiem 
ojczystym, polegającą na korzystaniu z aktywowanych zasobów pamięci długotrwałej zawierającej wiedzę o znanych im językach. Znajomość większej liczby języków oznacza większą zdolność do myślenia przez analogię, do analizy i syntezy nowych danych oraz aktywowania schematów poznawczych. $Z$ tego powodu uczniowie posługujący się kilkoma językami z większą łatwością uczą się kolejnych. W tym samym roku Skehan (1998) stwierdził, że osoby utalentowane językowo nie różnią się jakościowo od przeciętnie zdolnych, czyli nie posiadają żadnych specyficznych cech $-z$ jednym wyjątkiem: nadzwyczajnych zasobów pamięci. Teza ta znajduje potwierdzenie praktycznie we wszystkich badaniach utalentowanych osób (Novoa, Fein i Obler, 1988; Schneiderman i Desmarais, 1988; loup i in., 1994; Papagno i Vallar, 1995; Biedroń, 2012; Biedroń i Pawlak, 2016), poliglotów (Erard, 2012; Hyltenstam, 2014) i sawantów (Smith i in., 2011; Treffert, 2011). W grupie osób utalentowanych klasyczne studium przypadku - 29-letni CJ znający biegle sześćjęzyków - stanowi przykład ponadprzeciętnych zdolności pamięciowych (Novoa, Fein i Obler, 1988). CJ był w stanie odtworzyć bezbłędnie dziewięć par cyfra - litera bezpośrednio po jednorazowej prezentacji oraz po upływie dwudziestu minut. Podobnie bezbłędnie odtwarzał długie sekwencje wyrazów oraz fragmentów prozy, co dowodzi jego znakomitej pamięci krótkotrwałej fonologicznej oraz długotrwałej. Różnice w zdolnościach pamięciowych widoczne są także u dzieci. Badanie loup (1989) wykazało, że dzieci niepotrafiące nauczyć się języka obcego nie posiadały niższej inteligencji od tych zdolniejszych, ale słabszą pamięć werbalną, zwłaszcza zdolność do odtworzenia informacji po upływie czasu.

Szczególny przypadek uzdolnień językowych stanowią sawanci. Są to jednostki utalentowane i funkcjonujące w spektrum autyzmu (ang. high functioning autism), czyli osoby wymagające pomocy w życiu codziennym ze względu na upośledzone umiejętności społeczne i w niektórych przypadkach na niską inteligencję, posiadające natomiast niezwykłą łatwość uczenia się kolejnych języków. Jednym z dobrze opisanych w literaturze przypadków jest Christopher (Smith i in., 2011), który w wieku 49 lat opanował na różnym poziomie 20 języków. IQ werbalne Christophera jest w normie i wynosi $98^{1}$, niewerbalne natomiast zaledwie 52, co uniemożliwia mu zrozumienie prostych zabaw dzieci czteroletnich. Christopher posiada typową dla sawanta znakomitą pamięć krótkotrwałą fonologiczną oraz długotrwałą, a także asymetryczny profil zdolności ogólnych i pamięciowych. Jest on w stanie zapamiętać olbrzymi zasób słów, lecz jego umiejętności posługiwania się dyskursem są

\footnotetext{
${ }^{1}$ IQ, czyli iloraz inteligencji, określa się w skali, przy czym średnia dla populacji wynosi 100. Wartości pomiędzy 85-115 określa się jako przeciętne, zarówno dla inteligencji werbalnej, jak i niewerbalnej (Hornowska, 2004).
} 
ograniczone. W praktyce oznacza to, że jest w stanie opanować język obcy w zakresie słownictwa, gramatyki i pewnych aspektów pragmatyki, lecz teksty tłumaczone przez niego często nie mają sensu. Innym interesującym przypadkiem jest Daniel Tammet cierpiący na zespół Aspergera, lecz posiadający normalne zdolności poznawcze. Tammet dysponuje nadzwyczajnymi werbalnymi zdolnościami pamięciowymi, matematycznymi oraz zdolnością synestezji; zdołał nauczyć się siedmiu języków, przy czym nauka islandzkiego zajęła mu zaledwie tydzień (Treffert, 2011).

Inną grupą uczniów języka obcego cieszących się znakomitą pamięcią są hiperpoligloci zbadani przez Erarda (2012). Są to osoby znające biegle minimum 11 języków obcych, przy czym znajomość ta była potwierdzona w każdym przypadku przez rodzimych użytkowników. Wspólnym mianownikiem hiperpoliglotów są: wrodzony talent, pasja, motywacja, determinacja oraz, oczywiście, zdolności pamięciowe. W tym względzie charakteryzuje ich doskonała werbalna pamięć krótkotrwała, robocza oraz zdolność do odtworzenia informacji po upływie czasu, czyli pamięć długotrwała. Posiadają oni również zdolność do szybkiego przełączania zasobów uwagi (alokacji), co świadczy o wysokiej wydajności centralnego systemu wykonawczego. W praktyce te zdolności umożliwiają im szybką i skuteczną naukę nowych języków, odnawianie znajomości tych przyswojonych dawniej oraz automatyczne przestawianie się na konwersację w różnych językach. Ta ostatnia umiejętność stanowi szczególną trudność także dla poligloty, gdyż nie wszystkie języki są jednakowo „aktywne", ponieważ oczywistym jest, że nikt nie posługuje się na co dzień kilkunastoma językami. Osoby te charakteryzuje też wysoka inteligencja (125) oraz skuteczne strategie uczenia się, zwłaszcza pamięciowe.

Osoby wielojęzyczne, ponadprzeciętnie uzdolnione i osiągające wysoki poziom kompetencji zostały zbadane przez Biedroń (2012). Były to 44 osoby znające co najmniej jeden język obcy na poziomie C1/C2 w przypadku osób młodszych (<23 lat) i co najmniej dwa na poziomie C1/C2 w przypadku starszych (23-35 lat). Były wśród nich także osoby szczególnie utalentowane, znające od pięciu do siedmiu języków obcych, które opanowały poniżej 27. roku życia. Badaną próbę charakteryzuje bardzo dobra pamięć werbalna krótkotrwała i robocza dotycząca zapamiętywania materiału leksykalnego oraz fonetyki i ponadprzeciętna w zakresie materiału liczbowego (powtarzanie cyfr), ale w tym przypadku różnica pomiędzy tą grupą a przeciętnie uzdolnionymi jest mniejsza. Ponadto osoby $w$ badanej próbie posiadają wysoką inteligencję ogólną, bardzo wysoką werbalną oraz w zakresie czynnika pamięci i odporności na dystraktory. Podsumowując, osoby bardzo zdolne, sawanci i poligloci posiadają bardzo dobrą pamięć werbalną zarówno w zakresie pętli fonologicznej, jak i centralnego systemu wykonawczego, co umożliwia im opanowanie 
obcego języka po okresie krytycznym do wysokiego poziomu kompetencji. Charakteryzują ich również doskonałe strategie uczenia się słownictwa oraz ponadprzeciętna pamięć długotrwała, co z kolei sprawia, że ślad pamięciowy jest trwalszy, a języki rzadko używane nie są szybko zapominane.

Pamięć jest tak charakterystycznym atrybutem osób ponadprzeciętnie uzdolnionych, że najnowszy test zdolności językowych skonstruowany przez zespół amerykańskich językoznawców i psychologów (Doughty i in., 2010; http:// www.casl.umd.edu/hilab), mający na celu prognostykę maksymalnych osiągnięć w nauce języków obcych po okresie krytycznym, opiera się w dużej mierze na różnych testach pamięci, w tym roboczej. Test ten został zweryfikowany przez Lincka $i$ in. (2013) i sklasyfikowany jako trafny do przewidywania bardzo wysokiej kompetencji, przy czym PR jest jednym z jej najlepszych predykatorów. Wydaje się zatem, że istnieją wystarczające dowody na to, by traktować PR jako komponent zdolności językowych (Wen i Skehan, 2011; Linck i in., 2013; Wen, 2015).

Nie wszystkie osoby dwu- i wielojęzyczne są ponadprzeciętnie uzdolnione. Znajomość kilku języków może być naturalnym skutkiem wychowania w środowisku posługującym się dwoma i więcej językami, niemniej osoby takie mają efektywniej działającą PR zarówno pod względem przechowania informacji, jak i zarządzania zasobami uwagi. Badania Bialystok i jej zespołu (Morales, Calvo i Bialystok, 2013), także Blom i in. (2014) stanowią dowód na pojemniejszą PR u dzieci dwujęzycznych w porównaniu z jednojęzycznymi, zwłaszcza w zakresie zasobów uwagi. Dowodzi to, że zdolności pamięciowe można rozwijać i że sprzyja temu nauka dodatkowych języków.

\section{Implikacje pedagogiczne}

Badania opisane w poprzedniej sekcji dowodzą, że istnieje wyraźna korelacja pomiędzy sukcesem w nauce języka a PR. Analogicznie, deficyty w obrębie subkomponentów tej różnicy indywidualnej skutkują problemami w nauce. Problem ten dotyczy także dzieci z ADHD. Borkowska i Zawadzka (2008) stwierdziły, że mają one mniej pojemną pętlę artykulacyjną niż dzieci bez tego deficytu. Czy zatem PR można rozwinąć, zrekompensować jej niski poziom doborem odpowiedniej metody bądź treningiem strategicznym? Odpowiedź na te pytania jest według wielu badaczy twierdząca, co daje pole manewru dla interwencji pedagogicznej, a także możliwości samodoskonalenia tej zdolności przez ucznia chcącego zwiększyć swój potencjał. Należy zauważyć, że podatność na trening jest wyjątkową cechą PR, odróżniającą ją od innych czynników poznawczych. W dydaktyce PR możemy wyróżnić dwa trendy (Williams, 2012): dostosowanie instrukcji do profilu poznawczego ucznia (Skehan, 2012) i trening mający na celu zwiększenie pojemności PR (Söderqvist i Nutley, 2015). 
Podobnie jak tradycyjne zdolności językowe, PR wpisuje się w model ATI (ang. aptitude - treatment - interaction), czyli metodę pozwalającą dopasować rodzaj instrukcji do profilu zdolności ucznia w celu optymalnego wykorzystania jego mocnych stron i zrekompensowania słabych (Robinson, 2002; Skehan, 2012; Vatz i in., 2013). Wytyczne co do stosowania tej metody podaje literatura (Hummel i French 2010; Gregersen i Maclntyre, 2014; Tare i in., 2014). Na początku należy zidentyfikować uczniów wykazujących deficyty PR, a następnie ustalić, czy dotyczą one pętli fonologicznej, czy centralnego systemu wykonawczego, aby interwencja była celowa i zindywidualizowana. Jak łatwo się domyśleć, nie jest to proste zadanie dla nauczyciela, który nie dość, że nie dysponuje odpowiednimi narzędziami, to dodatkowo podlega różnorodnym ograniczeniom instytucjonalnym. Jednak nawet bez głębokiej wiedzy psychologicznej czy stosowania testów diagnostycznych można zauważyć niepokojące symptomy nadmiernego obciążenia PR. Należą do nich: niezdolność lub ograniczona zdolność do przypomnienia sobie informacji, problemy z rozumieniem i realizacją instrukcji, ze skupieniem uwagi, z usiedzeniem $w$ jednym miejscu, a także niedokańczanie zadań. Ponadto uczniowie z takim deficytem nie radzą sobie w nauczaniu komunikacyjnym, gdzie kładzie się duży nacisk na słuchanie. Jak stwierdziliśmy we wstępie, PR jest zmienną modyfikującą skuteczność różnych form instrukcji, ponieważ uczniowie z jej małą pojemnością mają problemy ze zwróceniem uwagi na formę gramatyczną, jeżeli zastosowana poprawa ma charakter przeformułowania lub stanowi inną instrukcję implicytną. Dla uczniów o małej pojemności PR bardziej zatem skuteczna będzie instrukcja eksplicytna, np. w formie wyjaśnienia zasady z podaniem przykładu użycia formy. Należy jednak pamiętać, że taka instrukcja nie przyczyni się do zamiany wiedzy deklaratywnej w proceduralną i niezbędna jest dodatkowa praktyka. Inne zadania i techniki rekomendowane dla uczniów z niską pojemnością PR obejmują przede wszystkim: ćwiczenia wstępne przygotowujące do wykonania zadania właściwego, przeznaczenie większej ilości czasu na planowanie, więcej powtórek i rezygnacja ze złożonych, trudnych poznawczo zadań na rzecz krótszych aktywności. W celu zniwelowania problemów ze zrozumieniem ze słuchu Gregersen i Maclntyre (2014) zalecają podejście multisensoryczne, czyli wykorzystanie różnych modalności, np. użycie wizualnych pomocy naukowych: posterów, schematów, konkretnych przedmiotów, wizualizacji oraz nagrań i technik multimedialnych. Szczególnie pomocne mogą być różnego rodzaju programy komputerowe. Osoby o dużych zasobach PR i wydajnym systemie uwagi odniosą większe korzyści z instrukcji bieżącej podawanej w trakcie wykonywania zadania, zadań skomplikowanych, bardziej czasochłonnych i wykonywanych bez uprzedniego przygotowania i planowania, jak np. ćwiczenia słuchowe czy tłumaczenie w czasie rzeczywistym, zadań 
interaktywnych i nauki słownictwa w kontekście. Dla takich osób implicytny sposób poprawy językowej wymagający zauważenia poprawnej formy będzie bardziej korzystny niż szczegółowa instrukcja.

Jeżeli chodzi o możliwość rozwoju PR, to istnieje bardzo dużo badań potwierdzających, że trening PR jest skuteczny i przynosi trwałe zmiany w funkcjonowaniu poznawczym. Badania w tym zakresie przeprowadził zespół Gathercole (2014; ponadto Gathercole, Lamont i Alloway, 2006; Gathercole i Alloway, 2008; Holmes i Gathercole, 2014). Dotyczyły one głównie deficytów PR skutkujących niskimi osiągnięciami szkolnymi u dzieci oraz technik pozwalających na zminimalizowanie tego problemu. Jak stwierdziliśmy, nauczyciele mają często ograniczone możliwości użycia programów komputerowych w celu rozwijania zdolności czy minimalizowania deficytów, lecz rodzice i uczniowie mogą uzyskać dostęp do odpowiednich programów w Internecie. Jednym $\mathrm{z}$ nich jest Cogmed working memory training (CWMT, http://www.cogmed.com). Jest to program opracowany przez szwedzki Instytut Karolinska na podstawie wyników badań neurologicznych wskazujących na plastyczność obszarów mózgu odpowiedzialnych za PR. Skuteczność metody we wszystkich grupach wiekowych i w obydwu krytycznych aspektach PR potwierdza 25 badań opublikowanych w recenzowanych czasopismach naukowych (Melby-Lervåg i Hulme, 2013; Cortese i in., 2015; Söderqvist i Nutley, 2015; SpencerSmith i Klingberg, 2015). Ćwiczenia PR skutkują statystycznie istotnym i trwałym zwiększeniem pojemności we wszystkich grupach wiekowych, od dzieci do starszych dorosłych, istotnym i trwałym zwiększeniem zasobów uwagi, jak również polepszeniem funkcjonowania szkolnego dzieci z niskimi wynikami w nauce i ADHD. Poprawę oszacowano średnio na $26 \%$ w przypadku komponentu wzrokowo-przestrzennego i $23 \% \mathrm{w}$ przypadku pętli fonologicznej. Istnieje również polski program komputerowy Neurogra (http://www.neurogra.pl) mający na celu zwiększanie zasobów PR, opracowany przez specjalistów ze Szkoły Wyższej Psychologii Społecznej, lecz badania kliniczne potwierdzające jego skuteczność nie są znane autorce tego artykułu.

\section{Wnioski i perspektywy dalszych badań}

PR stanowi ważną zmienną modyfikującą przebieg procesu nauki języka obcego. Zarówno dzieci, jak i dorośli cieszący się wydajną pojemnością pętli fonologicznej i skutecznym mechanizmem kontroli uwagi uczą się języka obcego szybciej i łatwiej, osiągając wyższe poziomy kompetencji. Podobnie jak inne czynniki poznawcze, PR jest czynnikiem wrodzonym, uwarunkowanym genetycznie, a jego deficyt obniża ogólny potencjał poznawczy i poziom osiągnięć szkolnych. Szczególnie wyraźnie ten deficyt przejawia się w przypadku dzieci z 
ADHD, a ze względu na wysoką korelację z inteligencją może dodatkowo wpływać na osiągnięcia szkolne u dzieci o inteligencji w dolnych granicach normy. Analogicznie osoby o wysokiej pojemności PR uczą się języków obcych z większą łatwością i osiągają wyższe poziomy kompetencji, nawet po zamknięciu okresu krytycznego dla nauki różnorodnych aspektów języka. PR koreluje dodatnio z sukcesem w nauce gramatyki, słownictwa oraz wszystkich umiejętności językowych w różnych warunkach uczenia się. Z powyższych względów tę zmienną wielu naukowców uznaje za zdolność językową (Wen, 2015). PR jest zmienną modyfikowalną, czego dowodzą badania w różnych grupach wiekowych dotyczące osób dwujęzycznych i jednostek wybitnie uzdolnionych oraz badania neurologiczne. Jest to wniosek bardzo optymistyczny, gdyż dotychczasowe próby zwiększenia zdolności poznawczych za pomocą treningu czy metod alternatywnych nie dały jednoznacznych wyników ani w kwestii trwałości zmiany, ani transferu na inne umiejętności.

W niniejszym artykule zostały przedstawione najważniejsze trendy związane z dydaktycznym wymiarem tej różnicy indywidualnej w kontekście nauki języka obcego. Należy zaznaczyć, że PR jest badana w takim kontekście od około 20 lat, przy czym nadal istnieje wiele wątpliwości, sprzeczności i aspektów niewystarczająco zbadanych bądź całkowicie zaniedbanych. Jednym z takich obszarów wymagających dalszych analiz są powiązania poszczególnych komponentów PR z różnorodnymi aspektami nauki języka. Np. nauka gramatyki i produkcja struktur gramatycznych są uwarunkowane funkcjonowaniem zarówno pętli fonologicznej, jak i centralnego systemu wykonawczego, lecz specyfika tej zależności jest słabo zbadana. Brakuje badań dotyczących wpływu centralnego systemu wykonawczego na poprawność mówienia, choć analiza teorii tego komponentu wskazuje, że wpływ taki istnieje. Bardzo mało jest też analiz korelacji pomiędzy PR a poziomem dyskursu językowego, gdyż większość badań odnosi się do leksyki bądź pojedynczej struktury. W kwestii narzędzi stosowanych do badania PR wśród naukowców istnieje względna zgodność co do metody badania poszczególnych komponentów, lecz brakuje ujednoliconych zasad analizy danych, np. kryteriów uwzględnianych przy zliczaniu wyników. Dokładniejsze ustalenie, jaki komponent PR wpływa na który aspekt języka, umożliwi efektywną interwencję pedagogiczną. Z punktu widzenia nauczyciela interesujące są wyniki badań wskazujących na skuteczność programów komputerowych zwiększających pojemność PR. Należałoby również zbadać, jak ten wzrost przekłada się na sukces w nauce języka obcego. W Polsce trwają prace nad skonstruowaniem narzędzi służących do badania obydwu kluczowych komponentów PR, czyli testu pseudosłów (ang. nonwords) badającego pętlę fonologiczną oraz testów czytania i słuchania (ang. reading span i listening span) badających centralny system wykonawczy 
(Biedroń, Zychowicz i Pasikowski, w przygotowaniu). Wszystkie testy są w języku polskim, co umożliwi rozpoczęcie badań nad PR w Polsce.

\section{BIBLIOGRAFIA}

Baddeley, A. D. 2000. „The episodic buffer: A new component of working memory?”. Trends in Cognitive Sciences, 4: 417-123.

Baddeley, A. D. 2015: „Working memory in second language learning”. (w) Working memory in second language acquisition and processing. (red. Z. E. Wen, M. B. Mota i A. McNeill). Bristol: Multilingual Matters, str. 17-28.

Baddeley, A. D., Gathercole, S. i C. Papagno. 1998. „The phonological loop as a language acquisition device”. Psychological Review, 105: 158-173.

Baddeley, A. D. i G. J. Hitch. 1974: „Working memory”. (w) The psychology of learning and motivation. Tom 8. (red. G. Bower). New York: Academic Press, str. 47-90.

Biedroń, A. 2012. Cognitive-affective profile of gifted adult foreign language learners. Słupsk: Wydawnictwo Naukowe Akademii Pomorskiej w Słupsku.

Biedroń, A. i M. Pawlak. 2016. „New conceptualizations of linguistic giftedness”. Language Teaching, 49(2): 151-185.

Biedroń, A. i A. Szczepaniak. 2012. „Working-memory and short-term memory abilities in accomplished multilinguals". The Modern Language Journal, 96: 290-306.

Biedroń, A., Zychowicz, K. i S. Pasikowski. (w przygotowaniu). „Reading span and nonword repetition - the development of tools to measure working memory in Polish learners". Studies in Second Language Learning and Teaching.

Blom, E., Küntay, A., Messer, M., Verhagen, J. i P. Leseman. 2014. „The benefits of being bilingual: Working memory in bilingual Turkish-Dutch children". Journal of Experimental Child Psychology, 128: 105-119.

Borkowska, A. R. i E. Zawadzka. 2008. „Verbal working memory in ADHD children”. Psychology of Language and Communication, 12(1): 71-84.

Bunting, M. i R. Engle. 2015: „Foreword”. (w) Working memory in second language acquisition and processing. (red. Z. E. Wen, M. B. Mota i A. McNeill). Bristol: Multilingual Matters, str. xvii-xxiv.

Conway, A. R. A., Jarrold, Ch., Kane, M. J., Miyake, A. i J. N. Towse. 2008: „Variation in working memory. An introduction". (w) Variation in working memory. (red. A. R. A. Conway, Ch. Jarrold, M. J. Kane, A. Miyakei i J. N. Towse). Oxford: Oxford University Press, str. 3-17.

Cortese, S., Ferrin, M., Brandeis, D., Buitelaar, J., Daley, D., Dittmann, R. W. i in. 2015. „Cognitive training for attention-deficit/hyperactivity disorder: Meta-analysis of clinical and neuropsychological outcomes from randomized controlled trials". Journal of the American Academy of Child and Adolescent Psychiatry, 54(3): 164-174.

DeKeyser, R. M. i J. Koeth. 2011: „Cognitive aptitudes for second language learning”. (w) Handbook of research in second language teaching and learning. (red. E. Hinkel). New York: Routledge, str. 395-407. 
Doughty, C., Clark, M., Cook, S. i M. Tare. 2013. „Needs analysis for tailored training (TTO 1004). CASL technical report". College Park, MD: Center for Advanced Study of Language.

Engle, R. W., Laughlin, J. E., Tuholski, S. W. i A. R. A. Conway. 1999. „Working memory, short-term memory, and general fluid intelligence: A latent-variable approach". Journal of Experimental Psychology: General,128(3): 309-331.

Erard, M. 2012. Babel no more. In search for the world's most extraordinary language learners. New York: Free Press.

Gathercole, S. 2014. „Working memory training, what training?”. Paper presented at the International Conference on Working Memory, Cambridge.

Gathercole, S. E. i T. P. Alloway. 2008: „Working memory and classroom learning”. (w) Cognitive development in K-3 classroom learning: Research applications. (red. K. Thurman i K. Fiorello). Mahwah, NJ: Lawrence Erlbaum, str. 15-38.

Gathercole, S. E., Lamont, E. i T. P. Alloway. 2006: „Working memory in the classroom”. (w) Working memory and education. (red. S. J. Pickering). Burlington, MA: Academic Press, str. 219-240.

Gregersen, T. i P. D. Maclntyre. 2014. Capitalizing on language learners' individuality. From premise to practice. Bristol: Multilingual Matters.

Holmes, J. i S. E. Gathercole. 2014. „Taking working memory training from the laboratory into schools". Educational Psychology: An International Journal of Experimental Educational Psychology, 34(4): 440-450.

Hornowska, E. 2004. Skala inteligencji dla dorosłych Davida Wechslera WAIS-R oraz WAIS-III. Warszawa: Wydawnictwo Naukowe Scholar.

Hummel, K. M. i L. French. 2010. „Phonological memory and implications for the second language classroom". Canadian Modern Language Review, 66(3): 371-391.

loup, G. 1989: „Immigrant children who have failed to acquire native English”. (w) Variation in second language acquisition. Tom II. Psycholinguistic issues. (red. S. Gass, C. Madden, D. Preston i L. Selinker). Clevedon: Multilingual Matters, str. 160-175.

loup, G., Boustagui, E., El Tigi, M. i M. Moselle. 1994. „Re-examining the CPH. A case study of successful adult SLA in a naturalistic environment". Studies in Second Language Acquisition, 16: 73-98.

Juffs, A. i M. Harrington. 2011. „Aspects of working memory in L2 learning”. Language Teaching, 44(2): 137-166.

Kormos, J. i A. Sáfár. 2008. „Phonological short-term memory, working memory and foreign language performance in intensive language learning". Bilingualism: Language and Cognition, 11(2): 261-271.

$\mathrm{Li}, \mathrm{S} .2015$. "The associations between language aptitude and second language grammar acquisition: A meta-analytic review of five decades of research". Applied Linguistics, 36(3): 385-408.

Linck, J. A., Hughes, M. M., Campbell, S. G., Silbert, N. H., Tare, M., Jackson, S. R. i C. J. Doughty. 2013. „Hi-LAB: A new measure of aptitude for high-level language proficiency". Language Learning, 63(30): 530-566. 
Linck, J. A., Osthus, P., Koeth, J. T. i M. F Bunting. 2014. „Working memory and second language comprehension and production: A meta-analysis”. Psychonomic Bulletin \& Review, 21(4): 861-883.

Mackey, A., Philip, J., Egi, T., Fujii, A. i T. Tatsumi. 2002: „Individual differences in working memory, noticing interactional feedback and L2 development". (w) Individual differences and instructed language learning. (red. P. Robinson). Philadelphia, PA: John Benjamins, str. 181-209.

Martin, K. I. i N. C. Ellis. 2012. „The roles of phonological STM and working memory in L2 grammar and vocabulary learning". Studies in Second Language Acquisition, 34(3): 379-413.

Melby-Lervåg, M. i C. Hulme. 2013. „Is working memory training effective? A metaanalytic review". Developmental Psychology, 49(2): 270-291.

Miyake, A. i N. P. Friedman. 1998: „Individual differences in second language proficiency: Working memory as language aptitude". (w) Foreign language learning. (red. A. Healy i L. Bourne). Mahwah, NJ: Lawrence Erlbaum, str. 339-364.

Morales, J., Calvo, A. i E. Bialystok. 2013. „Working memory development in monolingual and bilingual children". Journal of Experimental Child Psychology, 114: 187-202.

Novoa, L., Fein, D. i L. K. Obler. 1988: „Talent in foreign languages: A case study”. (w) The exceptional brain: Neuropsychology of talent and special abilities. (red. L. K. Obler i D. Fein). New York: Guilford Press, str. 294-302.

Papagno, C. i G. Vallar. 1995. „Verbal short-term memory and vocabulary learning in polyglots". Quarterly Journal of Experimental Psychology, 38A: 98-107.

Plomin, R. i J. Deary. 2015. „Genetics and intelligence differences: Five special findings". Molecular Psychiatry, 20: 98-108.

Robinson, P. 2002: „Learning conditions, aptitude complexes and SLA: A framework for research and pedagogy". (w) Individual differences and instructed language learning. (red. P. Robinson). Philadelphia, PA: John Benjamins, str. 113-133.

Robinson, P. 2003: "Attention and memory during SLA”. (w) The handbook of second language acquisition. (red. C. J. Doughty i M. H. Long). Oxford: Blackwell Publishing, str. 631-679.

Sawyer, M. i L. Ranta. 2001: „Aptitude, individual differences, and instructional design". (w) Cognition and second language instruction. (red. P. Robinson). Cambridge: Cambridge University Press, str. 319-354.

Schneiderman, E. I. i C. Desmarais. 1988. „The talented language learner: Some preliminary findings". Second Language Research, 4(2): 91-109.

Skehan, P. 1998. A cognitive approach to language learning. Oxford: Oxford University Press. Skehan, P. 2002: „Theorising and updating aptitude”. (w) Individual differences and instructed language learning. (red. P. Robinson). Philadelphia, PA: John Benjamins, str. 169-195.

Skehan, P. 2012: „Language aptitude”. (w) The Routledge handbook of second language acquisition. (red. S. Gass i A. Mackey). Abingdon: Routledge, str. 381-395.

Skehan, P. 2015: „Working memory and second language performance: A commentary”. (w) Working memory in second language acquisition and processing. (red. Z. E. Wen, M. B. Mota i A. McNeill). Bristol: Multilingual Matters, str. 189-204. 
Smith, N., Tsimpli, I., Morgan, G. i B. Woll. 2011. The signs of a savant. Language against the odds. Cambridge: Cambridge University Press.

Spencer-Smith, M. i T. Klingberg. 2015. „Benefits of a working memory training program for inattention in daily life: a systematic review and meta-analysis". PLoS ONE, 10(3). [online:.http://dx.doi.org/10.1371/journal.pone.0119522; DW 20.05.2015].

Tare, M., Bonilla, C., Vatz, K., Clark, M., Linck, J. i C. J. Doughty. 2014. Building a language learner's profile. Characteristics which inform training and pedagogy. University of Maryland Center for Advanced Study of Language.

Vatz, K., Tare, M., Jackson, S. R. i C. Doughty. 2013: „Aptitude-treatment interaction in second language acquisition: Findings and methodology". (w) Sensitive periods, language aptitude, and ultimate L2 attainment. (red. G. Granena i M. H. Long). Amsterdam: John Benjamins, str. 273-292.

Wen, Z. E. 2015: „Working memory in second language acquisition and processing: The phonological/executive model". (w) Working memory in second language acquisition and processing. (red. Z. E. Wen, M. B. Mota i A. McNeill). Bristol: Multilingual Matters, str. 41-62.

Wen, Z. E., Mota, M. B. i A. McNeill. 2015: „Introduction and overview”. (w) Working memory in second language acquisition and processing. (red. Z. E. Wen, M. B. Mota i A. McNeill). Bristol: Multilingual Matters, str. 1-14.

Wen, Z. E. i P. Skehan. 2011. „A new perspective on foreign language aptitude: Building and supporting a case for 'working memory as language aptitude'". Ilha Do Desterro: A Journal of English Language, Literatures and Cultural Studies, 60: 9-34.

Williams, J. N. 2012: „Working memory and SLA”. (w) The Routledge handbook of second language acquisition. (red. S. Gass i A. Mackey). Abingdon: Routledge, str. 427-441.

Williams, J. N. i P. Lovatt. 2003. „Phonological memory and rule learning”. Language Learning, 53: 67-121.

\section{Netografia}

Doughty, C. J., Campbell, S. G., Mislevy, M. A., Bunting, M. F., Bowles, A. R. i J. T. Koeth. 2010: „Predicting near-native ability: The factor structure and reliability of Hi-LAB”. (w) Selected proceedings of the 2008 Second Language Research Forum. (red. M. T. Prior, Y. Watanabe i S-K. Lee). Somerville, MA: Cascadilla Proceedings Project, str. 10-31. [online: http://www.lingref.com, document \#2382; DW 20.05.2015].

Hyltenstam, K. 2014. The Polyglot, online project description. Centre for Research on Bilingualism, Stockholm University. [online: http://www.biling.su.se/english/ research/the-program-aaa; DW 20.05.2015].

Söderqvist, S. i S. Nutley. 2015. Cogmed Working Memory Training. Claims \& Evidence, Complete Version. Pearson Clinical Assessment. [online: http://www.cogmed.com; DW 20.05.2015].

Treffert, D. A. 2011. „Daniel Tammet - Brainman: Numbers are my friends”. [online: http://www.wisconsinmedicalsociety.org/savant_syndrome/savant_profiles/ daniel_tammet; DW 20.05.2015]. 